\title{
What Do the Open-eyed Faith of Religious Feminists and the Existentialist Faith of Kierkegaard Have in Common?
}

\author{
Hannah Kehat \\ Kibbutzim College_-Tel Aviv, Givat Washington College, Israel
}

\begin{abstract}
Feminist theology has developed from the seventies of the twentieth century both as a movement of spiritual feminists - The theologians who themselves as implementing a radical breakaway from Western monotheism, developing Goddess Feminism in its stead. And as part of religious feminists, that despite the feminist criticism of patriarchal theology, they choose to maintain a traditional continuity of faith and religion. There are many similarities between this theology and the theology of existentialism of Soren Kierkegaard. Both are characterized by a critique of that established religion, both are aware of biases and interests of historical religions, and both reveal a choice to believe in God, a sober and authentic faith at the same time. The both are devoted to the metaphysical experience of faith, despite the historical corruption of religion. Feminist theology has criticized the gender bias of the Patriarchate, who designed the image of God as a man, a father. The tendency to create a feminist discourse of feminine aspects of God-the Goddess, compatible with Kierkegaard's existential faith, which emphasizes the imminence of God's existence. Alongside the similarities, there are large gaps between the feminist conception of life, Kierkegaard's religious concept, of devotion, detachment and self-sacrifice.
\end{abstract}

Keywords: feminist theology, Soren Kierkegaard, Goddess feminism, existentialism

I fear that I must begin my lecture with a quote from Kierkegaard himself:

People understand me so poorly that they don't even understand my complaint about them not understanding me.

My article seeks to examine the question of my religious-feminist faith and what it has in common with Kierkegaard's existentialist faith.

\begin{abstract}
A Brief Introduction
There is a dialectic connection between feminist religious theology and that of Kierkegaard. A feminist woman who is also religious is on the one hand rebelling against tradition, yet on the other not ready to give up her authentic faith in God. Her relationship with Kierkegaard's way of faith is ambivalent. On the one hand, the feminist religious woman's path is existential and her spirit is one of faith and a relationship with God without any commitment to objective, logical thought. Similarly, the feminist believer does not live her life based on a rational decision regarding the existence of God or the question of whether God commanded us to fulfill His religious injunctions. Her faith is an authentic existential experience based on the decision that she is not going to give it up. It is an experience of a maternal-immanent sense of the divine. It is not a discourse based on rational choice, but rather an open-eyed decision to maintain continuity with tradition. On the other hand, there
\end{abstract}

Hannah Kehat, Ph.D, Kibbutzim College-Tel Aviv, Givat Washington College. 
is significant disagreement between the two approaches. Feminist theology is highly critical of naive faith and objects to patriarchal approaches that refrain from criticizing the traditional masculine God.

Until the 1970s, the accepted view was to consider feminism and religion as two conflicting and mutually-exclusive persuasions: Feminism was anti-religious while religion abhorred and feared the women's movement. In her book The Woman's Bible, Elizabeth Cady Stanton (USA, 1815-1902), the leader of the suffragist movement in the United States, exposed the patriarchal perceptions in the Bible that exclude women. The book caused a huge scandal and the religious establishment denounced it as the "work of Satan and women". This feminist approach continued well into the 20th century. Its most quintessential representatives were the writer and philosopher Simone de Beauvoir (France, 1908-1986) (author of The Second Sex), and Kate Millett (Minnesota, 1934), a radical American feminist who in the 1960s wrote her famous study Sexual Politics and coined the term "gender". Millet was the first to note that the Abrahamic religions perpetuate patriarchy and the masculinity of religion by portraying the nature and origin of woman as dangerous and impure. She declared: "God is on the side of patriarchy". In The Second Sex, Simone de Beauvoir discusses the denial of the transcendental nature of women in religious faiths that marginalize and exclude women and that relegate them to an inferior status by objectifying them. A graver outcome of their physical oppression is the fact that, for the most part, they enslave their spirits and are unable to experience the fullness of their spirituality. They experience immanent, natural, instinctive lives, without a spiritual, sublime ideal worthy of every person created in God's image.

In The Second Sex, Simone de Beauvoir explained:

Every individual concerned with justifying his existence experiences his existence as an indefinite to transcend himself. But what singularly defines the situation of woman is that being, like all humans... an attempt is made to freeze her as an object and doom her to immanence, since her transcendence will be forever transcended by another essential and sovereign consciousness...

How, in the feminine condition, can a human being accomplish herself? What paths are open to her? Which ones lead to dead ends? How can she find independence within dependence...?

The 1970s saw a process of upheaval. Despite the harsh criticism of religion and the deconstruction of the Holy Scriptures, women began looking for spiritual fulfillment, and a new process of feminist spiritual-religious self-determination began. It should be noted at this point that the criticism of theology was shared by all the feminist movements, although the theological direction can be divided into two main currents:

(1) Spiritual feminists - the theologians: These feminists see themselves as implementing a radical departure from Western monotheism, developing Goddess Feminism in its stead;

(2) Religious feminists: Despite feminist criticism of patriarchal theology, they choose to maintain a traditional continuity of faith and religion. I would like to present and explain this path by means of Kierkegaard's teachings, as I engage in a dialectic disagreement with him.

These two currents are based on feminist criticism that attacks patriarchal theology: Mary Daly (USA, 1928-2010) was one of the most influential critics of religion. Despite Daly's attempts to remain part of the traditional Catholic framework, she found it impossible to do so. Her feminist studies undermined the entire symbolic system of patriarchal religion. In her article "The Spiritual Dimension of Women's Liberation"(Daly, 1971), she declared the women's movement a "spiritual movement" and argued that it had the potential to inspire a new and post-patriarchal spiritual movement. 
In the fall of 1971, Daly urged women to rise up and follow her in leaving the church, thereby symbolically abandoning patriarchal religion. Daly maintained that "We cannot be part of institutionalized religion as it currently exists; Singing sexist hymns and praying to a male god breaks our spirit, makes us less than human". Hundreds of women responded to Daly's appeal at that church event.

In 1973, Daly began to use female images to express the divine and called upon women to write religious texts by and for them. In her book, Beyond God the Father, the Goddess movement formulated a number of major themes.

(1) The andocentric perception of God presents him as transcendental (sublime, separate, and remote). His relationship with the world is one of infantile subordination and laws, and the religious individual realizes his faith by obeying and submitting to God and to the hierarchal religious leadership, while striving for an ideal of holiness and asceticism, and an acceptance of the distinction between the body and the spirit. All these are the result of an entire complexity of cultural approaches and structures that emanate from a masculine mindset and the characteristics of the patriarchal regime. Additionally, the patriarchy involves an act of duplication: The male image of God structures a built-in advantage for the male and sustains the patriarchal hierarchy and enslavement of women to men, similar to the enslavement of man to God in transcendental monotheism.

(2) The feminist perception of the Goddess is one of imminent, embracing and sharing beings who sustains us. Were faith based on the perception of the female Goddess, we might not be describing the act of creation as being ex nihilo, but might perhaps prefer a birth image, as was the case for other religions in ancient times. This image creates a poetic expression of a constant closeness to God in a world that so often seems hostile, alienated and meaningless. In contrast to the image of obedience and laws, a creation image of this kind would underscore the importance of religious sentiment and the presence of a direct God in the experience of motherhood, in the biological feelings that are unique to women and their self-perception as serving God in their day-to-day concrete acts of charity and help to others. The feeling is that if these elements had been emphasized rather than existing components of patriarchal tradition, the emotional, personal and intimate character of feminine religiosity would receive more clear expression

In her book Beyond God the Father, Mary Daly attacked Christian dogma regarding the revelation of God as Jesus the man. In her opinion, this requires a "leap of faith" that is "inauthentic and even idolatrous". She further claimed that divinity in a male form is exactly what cannot under any circumstances save humanity from the horrors of the patriarchal world. If God in his heaven is "a father who rules over his nation", then "it is only natural" that the world below will be dominated by the male, because "if God is male, then male is God". Women living under a patriarchy are a part of a lower caste. This status is not stated explicitly, but is rather masked, mainly by the division into gender-based roles supported by religion.

Although in her book The Church and the Second Sex, Daly explored the critical damage the church inflicted on women and their status, she differentiated the term theology from its normal limited and limiting context, as relating to institutionalized religion. She considered the patriarchal religious approach to be a distortion of the human aspiration towards the transcendental. Daly believed that the women's movement would give rise to a new language of the transcendental, and indeed she created a new feminist theology and philosophy that led to a new stage in the human spirit's search for God. According to Daly, the divine force is one of which all finite beings are parts, but not on a one-to-one basis, "Since this force is inside everyone and at the same time transcends everyone". Daly suggested that women understand divinity not as a noun but as a new means of perception of an immanent, dynamic and active presence that could reveal itself at any moment in 
every individual. She expressed movement of return to transcendentalism, the spiritual aspiration, the yearning for divinity and existential faith. From that time forward, the growth of the age of new spiritualism, which is largely feminist, began.

In the 1970s, feminism also began to awaken among religious women, both Christian and Jewish. Women raised in religious homes published numerous articles in which they discussed the great difficulty they encountered in persevering in their religious faith in light of their feminist awareness that their heritage was masculine. Extensive work in the fields of feminist commentary and theology ensued, including discussion on how the Bible treated women and on the andocentric aspects of faith and law. In 1973, Rachel Adler wrote the article "The Jew who wasn't there", referring to the Jewish woman who, according to the Bible, was apparently not present at the revelation at Sinai. Judith Plaskow, a prominent spokesperson for Jewish feminism, wrote an article in 1976 entitled "The Jewish Feminist: Conflict in Identities".

Yet religious women refused to abandon their identity and religious faith. In 1989, Cynthia Ozick wrote an article "Notes toward finding the right question", in which she reviewed the books and articles of the Jewish feminists that preceded her, and discussed what the principal challenge facing these women was. The answer was provided by Judith Plaskow: "The right question is theological". Plaskow's Standing Again at Sinai echoed the themes explored by Mary Daly. We can renew the covenant with God from the place of our feminist existence. Rachel Adler wrote her important book Engendering Judaism.

Today there are religious feminist movements in all three Abrahamic religions. In the area of religious philosophy, the theology of the feminist approach delves deeply into religious thought and influences all levels of faith and religious life. Feminist women often refer to God using the word Shekhina, which is the image of the immanent, compassionate and forgiving mother. Women have developed theological ways to contain the materialization of the divine in feminist history as part of the Jewish heritage, and in the expansion of the revelation of God's new face - as a mother, to complement the masculine face.

Religious feminist women come under fire from all directions. Secular feminists refuse to accept that these women have chosen to remain religious. Thus, for example, the Israeli feminist Arianna Melamed wrote a long diatribe against religious feminists who insist on remaining within Orthodoxy (March 8, 2011):

Always the same story. You're not alone, sister. If you look a little beyond your own Jewish world, you will find-it must be the work of the devil - that in the more traditional denominations of the three large monotheistic religions, women are still looked upon as having been created from Adam's rib rather than in God's image. It's a fact: The Catholic Church still does not accept women into the priesthood, only male judges may preside in Muslim courts and as for you, men alone will decide what is proper for your body and soul, along with your fate.

Religious communities, on the other hand, condemn them for their attempt to present a new agenda for religion, one that is predominantly feminist.

What motivates religious women not to abandon their religious faith (a step that would appear to be self-evident and rational), but rather to cling to their faith and not abandon their religion and patriarchal God?

The feminist religious woman refuses to make a dichotomous choice between secularity and religion, tradition and disengagement. Rachel Adler wrote: "What will bring me up from the Passover Seder table and say 'This is not for me'? Women are also part of the heritage, should I say to Mary Wollstonecraft and Doris Lessing, 'You are my heritage'?" This resistance is similar to the unwillingness of women of other minorities to abandon their identity and their ethnicity during feminist development. Examples include African-American women such as Bell Hooks, author of Feminism Is for Everybody or members of the Israeli organization Achoti 
("My Sister") that represent Mizrachi (Eastern) feminists.

It is also possible to identify a belief in God that constitutes a dominant factor in the religious woman's choice to adhere to religion. The faith experience of a woman who grew up in a faith community is not dependent only on scientific considerations and rationality. The discourse of religious women, even when they become feminist, is still a discourse of faith in God.

In this intersection of the tension between tradition and faith, Kierkegaard became an inspiration for religious feminists' choice to prefer personal authentic faith over the objective decision, relying on his existential philosophy, recognizing the value and necessity of existential experience as Kierkegaard wrote: "My task has continually been to provide the existential-corrective by poetically presenting the ideals and inciting people".

Two basic features can be said to characterize his thought: the existential aim of changing the reader's life by poetic-literary means; and the indirect tactics. This is where Kierkegaard's existentialist theology plays such an important role for feminist theology. We can say that the most significant element of Kierkegaard's philosophy is this absence of doubt of faith. The experience of confessions of faith in God, even when faced with a paradox arises. The similarity is in the point of origin and not the horizon. Unlike Kierkegaard, the concept of the religious feminist, especially the Jewish one, does not lay in unfathomable transcendence. The common ground between his theology and the faith of the religious feminist is the existential and authentic point of departure that led these women to cling to their identity and their experience of faith on their way to creating a new relationship with God. They are not, however, aligned with the transcendent conception of God.

Thus we can see a close relationship between the authentic faith of the religious feminist and Kierkegaard's existential philosophy. Her faith is also based on an existential theological foundation and derives its meaning particular from the existentialism of Kierkegaard.

At the same time, there are significant differences between the perceptions of Kierkegaard's belief and that of feminist theology, and I shall seek to explain these in the next section. Feminist believers, as revealed to us in the last generation, reject the theological basics of dichotomous faith that appear in Kierkegaard's philosophy, and they also reject the demand for sacrifice as this appears as a fundamental cause of faith in his book Fear and Trembling.

Kierkegaard's theological heritage offers two contradictory aspects in this context: identity and criticism.

Clinging to faith, perhaps contrary to what is rational, closely reflects what Kierkegaard said about Abraham, who departed from his homeland on the strength of his faith, became a stranger in the Promised Land, leaving his rational self behind in his native land. I cannot believe that a feminist woman who clings to her faith in God and strives for a spiritual life could have taken that route, if Kierkegaard had not gone before her in his special, authentic way. The experience of clinging to God, which is so existential and characteristic of Kierkegaard, also typifies the woman who remains a believer despite being a feminist. She has chosen to dwell with God, as Kierkegaard put it. That feminist woman finds herself completely identifying with these words by Kierkegaard:

(1) If I am capable of grasping God objectively, I do not believe, but precisely because I cannot do this, I must believe;

(2) Just as in earthly life lovers long for the moment when they are able to breathe forth their love for each other, to let their souls blend in a soft whisper, so the mystic longs for the moment when in prayer he can, as it were, creep into God; 
(3) Faith is the highest passion in a human being. Many in every generation may not come that far, but none comes further;

(4) It is the truth that exists for God. The standard of measure and the end is superhuman; and there is only one relationship possible: faith;

(5) Climacus (Kierkegaard) about the faith: The most mistaken impression one can have of it is that it is didactic, on the contrary, it is riddled with irony, parody and satire.

Paradox and passion feet each other perfectly.

In addition, the experience of faith, as described by Kierkegaard as one that distinguishes the believer from the disbelievers surrounding her, can faithfully represent the religious feminist, in spite of the fact that she has renewed the covenant in wake of shattering the traditional masculine theology. She can also identify with familiar statements by Kierkegaard, such as: "To defend something is always to discredit it", or his assertion that truth is a snare: "You cannot have it, without being caught. You cannot have the truth in such a way that you catch it, but only in such a way that it catches you". He imagined a life of faith as a ship that has sprung a leak, and the believer as a traveler who is enthusiastically struggling to keep the ship afloat by pumping and not by seeking the harbor.

However, the feminist's gender disillusionment and feminist criticism distinguish her from Kierkegaard and his willingness to submit to religious values that emanate from a masculine theology, and especially to view self-effacement as an exalted ideal, along with a willingness to sacrifice everything, even one's own child. Kierkegaard wrote about the self-sacrifice in the binding of Isaac: "And yet was Abraham God's chosen one, and yet was it the Lord that tempted him. And now all was to be lost". He praised the choice of obedience and submission to God; the joy of self-worship and self-effacement before God.

Religious feminists protest the total commitment and faith as presented in Kierkegaard's book Fear and Trembling, as well as Abraham's willingness to sacrifice Isaac. To believe as a feminist does not require obedience. The commitment to obey emanates from a transcendental, patriarchal approach based on hierarchal authority, dominance and submission. That is the father figure. The mother figure does not demand submissiveness and remoteness, but rather connection and reciprocity. It is an existential faith, but also one that is critical and suspicious, because it treads in a field that for thousands of years was plowed by men using male plows.

Kierkegaard's existential formulation for an authentic life is also incompatible with the feminist approach, since it is independent and individualistic, whereas woman is connected and does not set herself apart. The title of one of Kierkegaard's well-known essays "Purity of heart is to will one thing" reflects a position according to which authenticity lies in the sincerity of intent, which is the "purity of heart" that is directed at a single object; according to Kierkegaard, this is the "good" or "God". In other words, personal authenticity is created from the action of pure yearning to become a truly authentic individual.

Women have difficulty living with an ethos that appears to be tainted with phallocentrism, seclusion, a focused orientation towards a remote, external objective, like an arrow pointed at a target. This is where the maternal, feminist theology of socialization, of the refusal to sacrifice the child, appears.

The well-known Israeli poet Hava Pinchas Cohen reflected this attitude in some of her poems. In one of them, entitled "A Prayer", the trauma of the Holocaust leads her to object to the binding of Isaac. She says to God: 
Do not try me, please

There are trees and thickets, smell of fire

And shows smoke

With mothers do not play games of hide and seek

In another poem begins by mentioning Kierkegaard's Fear and Trembling, the raised hands of Moses and the prayers of the Jewish New Year which are identified with anxiety. It makes clear that she corresponds with this ideas in her poem. She writes about the difference between her and they, Moses and Kierkegaard:

Fear and trembling, kierkegaard New year prayers

This movement of infinite resignation

Moses' hands

Directs my actions

And in this movement

Moshe's hands

And my eyes

Do not meet

He on the mountain and I'm sitting on the river

And a world of downward looking at me

From the depths

However, I would like to emphasize that this choice to refashion religious faith following rebellion and conciliation, is in fact the path of Kierkegaard too, as Jacob Golomb wrote:

Kierkegaard, and most of the theorists of authenticity that followed him, believed that man becomes what he is after a prolonged rebellion against what he is. The rebellion against and acceptance of the object of rebellion shape man out of true freedom, as long as he does not accept his past and self as self-evident from God, i.e., in the sense of entities having an unalterable, fixed and frozen essence.

Kierkegaard believed that man becomes what he is after he ceases to be what he is not. His personal solution to the problem of personal identity was to return to the "abandoned" religious self and once again draw on its religious roots. This is the source of his demand to associate authenticity with faith: in order to attain authenticity, Kierkegaard had to first find the hidden meaning of his life. He had to explain it to himself and make himself conscious of it, because without a certain measure of self-knowledge, it is not possible to achieve personal authenticity.

Religious feminism shares a lot with Kierkegaard, who wrote: "Leap of faith-Yes, but only after reflection"1.

\footnotetext{
${ }^{1}$ I should emphasize that I am not attempting here a feminist reading of Kierkegaard. For an example of such a reading, see: Celine Leon \& Sylvia Walsh (eds.), Feminist Interpretations of Søren Kierkegaard (University Park: Pennsylvania State University Press, 1997). A major question that this book explores is whether Kierkegaard's writings are misogynist, ambivalent or essentialist in their views of woman and the feminine, or whether, in some important and crucial way, they are liberating and empowering for feminists and women seeking to free themselves from the maze of patriarchal constructs. The essays also show how the three existence-spheres - aesthetic, ethical and religious - articulated by Kierkegaard describe different modalities of the sexual relation: seduction for the aesthetic, marriage for the ethical and absence from commerce with the other sex for the religious. However, my article focuses on the question of religious-feminist faith and what this shares with Kierkegaard's existentialist faith.
} 


\section{References}

Adler, R. (1973). The Jew who wasn't there (Response 18, pp. 77-82).

Adler, R. (1997). Engendering Judaism: An inclusive theology and ethics (p. 50). Philadelphia: Jewish Publication Society.

Alexander, D. (1938). The Journals of Søren Kierkegaard. London: Oxford University Press. Bretall, R. (Ed.) (1946). A Kierkegaard anthology (pp. 215, 219). Princeton: Princeton University Press.

Golomb, J. (1991). Kierkegaard's ironic ladder to authentic faith. Philosophy of Religion, 32, 65-81.

Golomb, J. (2008). In his introduction to the Hebrew translation of At this time, back, the difference between genius and messenger. Jerusalem: Magnes Press.

Daly, M. (1973). Post-Christian theology, some connections between idolatry and methodolatry. Address given at the Annual Meeting of the American Academy of Religion.

Daly, M. (1973). The spiritual dimension of women's liberation. In A. K. Ellen Livne, \& A.Rapone (Eds.), Radical feminism (pp. 260, 263). New York: Quadrangle Books.

Daly, M. (1973). Beyond God the Father: Toward a philosophy of women's liberation (p. 6). Boston: Beacon Press.

Daly, M. (1992). Outercourse: The bedazzling voyage, containing recollections from my logbook of a radical feminist philosopher (pp. 140-141). San Francisco: Harper.

De Beauvoir, S. (1952). The second sex (trans. H. M. Parshley). New York: Alfred A. Knopf.

Hooks, B. (2000). Feminism is for everybody: Passionate politics. Cambridge, M.A.: South End Press.

Kierkegaard, S. (1938). Purity of heart is to will one thing, spiritual preparation for the office of confession. New York: Harper \& Brothers.

Kierkegaard, S. (1980). The sickness unto death (trans. Howard V. Hong \& Edna H. Hong, Part 2, Chap. 1). Princeton: Princeton University Press.

Kierkegaard, S. (1983). Fear and trembling (trans. Howard V. Hong, \& Edna H. Hong, pp. 19-20, 59, 85). Princeton: Princeton University Press.

Kierkegaard, S. (1995). Works of love (trans. Howard V. Hong and Edna H. Hong). Princeton: Princeton University Press.

Kierkegaard, S. (1997). Writing sampler (trans. Todd W. Nichol, pp. 112, 188). Princeton: Princeton University Press.

Kierkegaard, S. (1997). Without authority including: The Lily in the field and the bird of the air, two ethical-religious essays, three discourses at the communion on fridays, an upbuilding discourse, two discourses at the communion on Fridays (trans. Howard V. Hong \& Edna H. Hong). Princeton: Princeton University Press.

King, U. (1989). Women and spirituality: Voices of protest \& promise (p. 138). Houndmills: Macmillan.

Millett, K. (1970). Sexual politics (Chap. 2). New York: Doubleday.

Ozick, C. (1983). Notes toward finding the right question. In S. Heschel (Ed.), On being a Jewish feminist: A reader (pp. 120-151). New York: Schocken Books..

Pinhas, H. C. (1995). Journey of the Doe (p. 26). Tel Aviv: HaKibbutz HaMeuchad, Ritmus Series.

Plaskow, J. (1990). Standing again at Sinai: Judaism from a feminist perspective. San Francisco: Harper.

Plaskow, J. (1976). The Jewish feminist: Conflict in identities. In: E. Koltun (Ed.), The Jewish woman: New perspectives (pp. 3-10). New York: Schocken Books.

Ross T., \& Gelman, J. (1998). Implications of feminism on the Orthodox Jewish Theology. In: M. Sagi and Shamir (Eds.), Multiculturalism in a democratic and Jewish State (pp. 443-464). Tel Aviv: Ramot Publishing-Tel Aviv University.

Stanton, E. C. (1985). The woman's bible: The original feminist attack on the bible. Edinburgh: Polygon Books. 